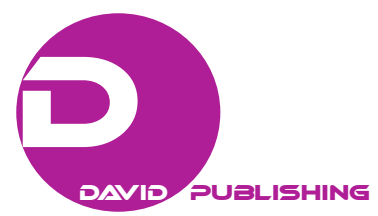

\title{
Transformation of Russian Military Enterprise in the Geopolitical During Putin Era*
}

\author{
WU Fei \\ Jinan University, Guangzhou, China \\ Charhar Institute, Beijing, China
}

\begin{abstract}
The quotation, from Vladimir Putin's annual address as president in 2006, neatly summaries the reason why Russia had to press forward with long-overdue reforms of its armed forces. Two decades after the fall of the Soviet Union, Russia was still left with an oversized military organization built for large-scale mobilization and the demands of the Cold War, but highly ineffective for the type of conventional military conflicts that Russia was most likely to become involved in. The rationale behind Russia's reforms of the armed forces were thus clear long before the war in Georgia, which has often been pointed to as the reason why the reforms were launched in October 2008. President Vladimir Putin's current period runs out in 2024, when he is due to step down, according to the Constitution. Given the fact that the current political system has been carefully crafted for almost 20 years, it is evident that there is uncertainty about its future. First, it no longer produces wealth for the population. For five years in a row, the real disposable income has been decreasing. Second, the legitimacy of the system could be questioned, since Putin's popularity figures are going down, and the surge from 2014-2015 has been eradicated. War as well (indeed, the Soviet Union helped fuel conflict and instability), the communist ideology and groups that professed it lost their main backer with the fall of the Soviet Union. Some African states weakened as the result, and coupled with an influx of arms on the global market, it was easy for disparate individuals and groups to carve out areas of influence under the barrel of a gun. In the U.S., private military companies (PMCs) emerged as "a function of decades of decisions underscored by both the strategic requirement for resources and neoliberal thinking. The desired result to recue costs, gain efficiencies, and create economies of scale".
\end{abstract}

Keywords: Vladimir Putin, PMC, defense military enterprise, Eurasians

I remember the conversation with the then chief of the General Staff very well.... In order to give an effective answer to the terrorists we needed to gather a force numbering at least 65000 men. But in all of the Ground Forces, there were 55,000 in battle-ready units, and these were scattered all over the country. An army of 1 million 400 thousand men, but there was no one who could go to war. (Vladimir Putin's Annual Address to Parliament in 2006)

\section{Development of PMC Between Government and Commercial Market}

Private military companies (PMCs) are not something new in the modern world full of local conflicts and unstable regions. PMCs are usually considered as a commercial enterprise offering specialized services for the

\footnotetext{
* This article support by National Social Science Fund Project: Research on the Construction of Institutional Discourse Right in Global Governance-An empirical study based on Sino-Russian Media Communication (全球治理中制度性话语权的构建研究 一基于中俄传媒交流的实证研究 16AZD052).

WU Fei, Ph.D., professor, Jinan University, Guangzhou, China; senior fellow, Charhar Institute, Beijing, China.
} 
safeguarding or protection of any objects, as well as for demining, training, maintenance, elicitation, strategic planning, logistics, and consulting. Private military companies are most often used where the task is beyond the power of civilian security companies, but for whatever reasons, it is impossible or impractical to involve a regular army.

The history of Russian PMCs dates back to the 1990s, when the first so-called "Russian volunteers" went to fight in Yugoslavia. The Federal Specifications Board (FSB) Officer Igor Strelkov-Girkin was among them. He is known for the capture of Slavyansk in the Donbass, Ukraine, in the spring of 2014, and is accused of involvement in the downing of the Malaysian Boeing MH17 in the sky over the Donbass on July 17, 2014.

In the case of Yugoslavia, it is safe to say that the Russians could not go abroad with combat gear and participate in hostilities without the authorization of the Russian leadership. According to some sources, in 1992-1995, on the territory of Bosnia, several hundred "Russian volunteers" were constantly operating, using the tactics of reconnaissance and sabotage groups. The basis of the unit consisted of fighters of the St. Petersburg security company under the name Rubicon. Without the participation of Russian special services and the Russian government, their activities would be impossible.

Under the same scheme, the Kremlin sent mercenaries linked with the special services of the Russian Federation under the guise of "volunteers inspired by the ideas of protecting Russia's interests" to Transnistria and Nagorno-Karabakh, and later to Georgia, the Crimea, the Donbass, and Syria.

It is worth noting that against the background of such illegal military activities, Russian military experts repeatedly appeared in various absolutely legal PMCs. In particular, Russians are actively involved in protecting vessels from Somali pirates. They also worked in western PMCs during the American campaign in Iraq. But these were the foreign PMCs in which citizens of the Russian Federation participated as private individuals.

Therefore, the need to regulate the activities of PMCs in Russia appeared, which would allow not only legalize the participation of Russians in private military companies, but would also enable the Kremlin to create PMCs legally to achieve its military and political goals outside of Russia.

\section{The Military Threat to Russia and State Defense Industries Transformation}

The most famous Russian PMC is the Wagner Group, owned by Yevgeny Prigozhin, an oligarch close to the Kremlin (known as "Putin's chef"). However, there are many other groups. In a February 2018 interview with Lenta.ru, an individual working for a PMC said,

Why is this private military company (PMC) allowed to work? This is hard for me to understand. I can assume that the whole thing is in the relationship of a particular person with a specific president. This practice has no world analogues.

His comment highlights the unique nature of Russian PMCs.

Scholars have divided private security companies (PSCs) into categories based on the types of functions they perform - ranging from analysis, to provision of goods and services to military forces, to acting as bodyguards. Private military companies, or private contractors-PMCs, are a different subset of PSCs and provide a very specific service- "kill or train others to kill” in foreign settings. PMCs primarily hire military veterans, "often those with a special-forces background". Russian PMCs overlap across these categories when it comes to their activities, and at times also engage in mercenary behavior. Not all individuals employed appear to have the special forces background. Some, for example, join these organizations in exchange for 
removal of their past criminal history. This is not the case with Western PMCs, where the system is more streamlined and transparent, and where PMCs tend to disassociate themselves from mercenary behavior.

Related to the confusion of definitions is that the need for and use of PMCs arose differently in the West than in Russia. Before the end of the Cold war, Western nations saw the state as the primary (though certainly not exclusive) employer of military power. The end of the Cold War changed that. With the collapse of the Soviet Union, multiple small-scale conflicts broke out worldwide, while the global market flooded with excess military equipment and specialists. Small conflicts and weapons flow proliferated during the Cold War to compete with the West in the realm of PMCs. Because the Kremlin could not challenge Western PMCs within the existing rules of the game, according to Sukhankin (2019), it had to change "the principles of the game itself". Ambiguity and confusion are other unique features of Russian PMCs. PMCs are illegal under Russian law, specifically the Russian Constitution. Chiefly, Article 13.5 prohibits "public associations" whose aims include "setting up armed units". Others had pointed out also that Article 71 of the Constitution deems matters of defense, security, war and foreign policy to the state although this point may reflect an underlying fear that such groups could overtake the state. After all, in Western countries that utilize PMCs do so in full accordance of the law, and these laws give the state power to carry out matters of defense, security, and foreign policy.

Indeed, PMCs clearly have links to the Kremlin, but they are not always controlled by the Russian state. This opacity provides the Russian state plausible deniability, another key unique feature of Russian PMCs. However, it is not the only unique feature. Opacity fits the pattern of behavior of weak and corrupt authoritarian states, rather than great powers. It is unclear how the illegality of PMCs contributes to plausible deniability for the Kremlin. But the illegality does help the state to maintain power dynamics and ensure loyalty within the rivalries of cronies around Putin. This point about plausible deniability and how the illegality of PMCs is useful to Putin highlights broader theme with regard to Russia - as it does not fit Western notions of great power or weak state behavior. Indeed, as historian Stephen Kotkin wrote, Russia has "almost always been a relatively weak great power". A strong state in the Western understanding of the term would not need to keep PMCs illegal in order to maintain its grip on power by hanging a sword of Damocles over rivaling groups. In this sense, the Kremlin's behavior with regard to PMCs is more characteristic of a mafia group than a strong state.

In 2009, as part of major reforms of the Russian armed forces, several units were transferred from the Glavnoe Razvedivatelnoe Upravlenie (GRU) to report directly to then-General Chief of Staff Nikolai Makarov. The next year, Makarov suggested publicly the use of PMCs "for delicate missions abroad...to avoid the humiliation of 2004", likely referring to the conviction in Doha over Yandarbiyev's murder. The onset of the Arab Spring and fighting in Libya and Syria, "magnified the Russian military strategists' focus on PMCs due to the changing nature of warfare". And in November 2012, Putin publicly supported the idea of using private military companies. When reporting on Putin's comment, RIA Novosti highlighted the point that countries that use PMCs abroad are primarily the U.S., Great Britain, and France.

In early 2012, the general staff unveiled the Special Operations Forces Command (Командование сил специальных операций, КССО in Russian), and in March 2013, Valeriy Gerasimov officially announced the creation of Special Operations Forces (SOF, Силыспециальных операций [CCO]), as part of the Special Operations Forces Command, which are separate from other branches of the Russian armed forces. The prototype for the SOF appears to have been the units created in 2009-2010 mentioned earlier. Gerasimov (2017) said as part of the announcement, "Having studied the practice of the formation, training and use of special operations forces of the leading states of the world, the leadership of the Russian Ministry of Defense has also 
begun to create them". Indeed, Moscow appears to have modelled the unit in part after elite, Western SOF. However, Russia's SOF hires exclusively on contract (per Russian definition of the term "contractor"), for officer positions. SOF operations, carried out usually in secret, are "under the direct control of senior military leaders or commanders-in-chief of the armed forces in theaters of war". The SOF has other unique features. According to Sukhankin (2019), they are "able to collaborate with local military formations", and are able to operate in smaller tactical groups, but without formal approval from the armed forces. The SOF is part of the story when it comes to understanding the origins of Russian PMCs under Putin, even as the SOF is formally part of the Russian armed forces. This model continued to expand and modify in the coming years.

\section{Defense Military Enterprise Show Russian Soft Power}

Russia developed its main security and foreign policy doctrines and strategies throughout the 1990s. It is clear that the Russian threat assessment in the Military Doctrines has been consistent-with only a few variations - since the first draft of the 1993 Military Doctrine (Izvestiia, 1993). In 1997, a concept of national security and an updated foreign policy concept were published (National Security Concept, 1997; Foreign Policy Concept, 1997). Although the Military Doctrine, in its initial year, took a more hard-liners approach to Russian national security, focusing on external military threats to a greater extent than the other documents in 1997, by the year 2000, the anti-Western view had become persistent in the political debate.

Russian foreign policy has two overall long-standing objectives. The first is to be recognized as a great power in world affairs, comparable to the United States. According to the current national security strategy (2015), one of Russia's long-term strategic interests is to consolidate its "status as a leading world power, whose actions are aimed at maintaining strategic stability and mutually beneficial partnerships in a polycentric world". In a similar way, the Foreign Policy Concept (2016) talked about the country's need to consolidate its status as "a center of influence in today's world".

Historically, the Russian defense industry has played an important role in Russian society. It has been argued that the Soviet Union did not have a military-industrial complex; rather it was one. By the 2000s, however, it was becoming increasingly misleading to refer to a Russian military-industrial complex in terms of a defense industry, armed forces and defense industry ministries operating as a single, integrated entity. Signs of deep dysfunctionality were increasingly apparent, and by 2016, the long-standing rifts between the defense leadership and the industry, as well as within the industry, were out in the open. The sector was no longer the state's primary focus; it had become dependent.

Since 2008, Russia's political leaders have intensified their efforts to steer the development of the country's defense industry. In addition to continued efforts to concentrate the defense industry in state-owned holding companies, a process begun in 2006-2007, the government has also sought to stimulate change from outside.

The Ministry of Defense, with the backing of the president and prime minister, has been proactive in this process, using a carrot and stick approach. As discussed in the previous chapter, the defense industry has been sharply criticized for price rises, poor quality and unpunctual delivery as well as widespread corruption. The Ministry of Defense has also, and for the first time, placed orders for large materiel systems with foreign defense industries. Meanwhile, a substantial increase in domestic orders is being planned. Moreover, companies' profit margins on priority materiel are expected to increase. Domestic defense orders since 2007 have exceeded arms export contracts by 50 percent. With the 2020 State Armament Programmed, government 
orders will become an even more important source of income for the Russian defense industry and thus a potentially stronger defense policy instrument.

After a period of high military spending, Russia's total military expenditure is now on a downward trend. It has fallen from over five percent to 3.8-3.9 percent of GDP, which represents a decrease, but this is still a high share compared to the other great powers, the US and China. This means that although Russia's spending in nominal terms is lower than that of its perceived potential adversaries, Russia continues to forsake a greater share of its GDP to at least maintain the higher level of military capability it has achieved thanks to the military reform, the GPV-2020, and prioritizing defense spending over other public spending during a period of falling economic growth. A reason for ascribing lower priority to defense now is that the military reform and the GPV-2020 have produced visible results. During recent years, Russia has been able to demonstrate its status as a military great power at home and abroad growth. Low growth hampers improvements in the population's living standard, which challenges the president's popularity rating, also another important priority. However, it is not through market reform that the president wants to restore growth; it is rather with administrative methods and by stipulating plan targets. A wide range of national projects has been created to accomplish ambitious goals regarding the economy's ranking internationally and the population's health and living standard. However, under present institutional arrangements, without economic reforms, it will be hard to raise growth sufficiently to achieve these goals.

The Russian defense industrial complex consists of approximately 1,350 organizations. It employs about two million people, although not all of them work on military production (Pravitelstvo Rossii, 2018). As a rule and in comparison with Western defense companies, Russian defense companies and organizations are more focused on defense production. A striking thing about the Russian defense industry is that there are very few small- and medium- sized enterprises (SMEs).

At the annual evaluation meeting on 22 November 2011, the Russian minister of defense, Anatolii Serdiukov, started by stating that the task of transforming the armed forces, giving them a "new look" (Novyi Oblik), had been fulfilled. However, he also pointed to a number of tasks ahead. And, in spite of the many problems and criticisms levelled against Serdiukov's reforms, the achievements so far are worth taking note of. Few believed that Serdiukov would be successful where earlier ministers of defense had failed, but three years after the reforms were launched, the results are impressive. In little more than three years, Russia has managed to downsize its bloated officer corps, to dismantle empty cadre units and to introduce a new command system as well as a new branch of arms. Although there are significant tasks ahead, there is every reason to note the scale and depth of the restructuring that has taken place inside Russia's armed forces.

The most recent large-scale military exercises, practicing and refining new concepts of employment of the Russian forces, serve as an illustration of the threat perceptions guiding the military transformation. They follow the pattern noted some time ago of exercises in Russia practicing offensive action in the West and defensive action in the East, and tally with the threat picture expressed during the Ladoga-2009 exercise by chief of the main staff of the Ground Troops Lt-Gen Sergey Skokov in the West, Russia has to contend with "innovative armies with non-contact forms and methods for using the latest forces and equipment", in the south, "irregular formations...[and] guerrilla warfare", and in the east, "a multi-million troop army using traditional approaches to the conducting of combat operations...with a great concentration of manpower and firing systems". Six months after this statement, Russia's new Military Doctrine emerged, containing a carefully nuanced treatment of North Atlantic Treaty Organization (NATO) and a studied silence on the subject of China. 
Contrary to much media reporting at the time, the new Doctrine signed into law by President Medvedev in February 2010 does not describe NATO as a military threat to Russia. But specific NATO activities (in particular, the development of military infrastructure closer to the borders of Russia, and use of force globally "in violation of international law") are noted as "military dangers" which could under certain circumstances lead to an immediate threat. At the forefront of Russian thinking in this respect are the Baltic States-within NATO but not subject to the restrictions of the unadapted Conventional Forces in Europe (CFE) Treaty-and any potential new members for NATO that could be found around the Baltic rim.

In 2019, the Russian defense budget (in the federal budget what is classified as "national defense") totaled 619.8 billion, corresponding to 2.9 percent of GDP. Data on the defense budget and defense expenditure as a share of GDP are of interest, as they reflect how big a burden defense allocation are for the rest of the economy. Changes in this share also give us an idea of whether the Ministry of Defense and the defense lobby have grown stronger or weaker in the budget process, in which public expenditure is decided. Defense expenditure as defined in the Russian defense budget lay, on average, at a level of 2.7 percent of GDP between 2009 and 2019. As the line "Russia/Federal Budget", the defense budget share of GDP is expected to increase over the next two years and amount to 3.9 percent in 2017.

The main cause of the rise in military expenditure as a share of GDP is the ongoing military reform and the fact that the state procurement of arms will increase. Arms procurement including research and development (R \& D), which accounted for around 20 percent of the defense budget in the early 2000s, was allocated almost 40 percent of the defense budget in 2014. The plan is to increase this share to almost 60 percent of the defense budget in 2018.

- costs of the Border Troops and Interior Ministry Troops

- certain costs for the Ministry for Civil Defense, Emergencies and Elimination of Consequences of Natural Disasters (MChS)

- certain costs for the security services

- subsidies for the closed cities

- military pensions.

There are different national definitions of military spending and Stockholm International Peace Research Institute (SIPRI) recalculates the national expenditure to accord with the SIPRI definition, with the help of country specialists. In the case of Russia, in principle, Cooper has based his estimates of total military expenditure on Russian budget data. Historically, SIPRI's estimates give defence shares of GDP that are about 1-1.5 percentage points above the official Russian figures, which means that estimated total military expenditure in the 2000s lay at a level of 3.5 and 4.3 percent of GDP.

The composition of the Russian defense budget is not easily discerned, since its breakdown into separate items of expenditure only becomes known when the budget is submitted to the Duma. However, many budget items are classified in this version, and researchers try to estimate their size. The armed forces are the largest item in the defense budget and amounted to nine percent of the federal budget in 2009 ( 2.3 percent of GDP). If total military expenditure, as estimated from Russian budget data, is used as a basis, the armed forces account for the bulk, or almost 50 percent of total military expenditure. A further 20 percent goes to the Interior Ministry Troops and other troops outside the armed forces. Nuclear weapons, which are a major priority, accounted for nine percent and pensions and social provision, such as housing, for six and seven percent, respectively, in 2016. 
The Ministry of Defense is in the process of reforming the state procurement system for weapons and equipment, which has been both corrupt and ineffective. According to Russia's chief military prosecutor, Sergei Fridinskii, 20 percent of the defense budget disappears every year. Fake invoices, fraudulent dealings and bribes are commonplace, and some observers believe the losses caused by practices may be twice as large. Major delays caused by friction in the procurement process, disagreement over prices and the defence industry's limited ability to supply military equipment of the standard required by the Ministry of Defense are more the rule than the exception. Then President Dmitrii Medvedev called attention to these problems and took the defense industry to task for its failure to deliver in 2011. Minister of Defense Serdiukov has sought to calm the industry's fears following this criticism by assuring it that no closures or major purchases abroad are planned. The Ministry of Defense, too, has been called to account for its failure to finalize orders in the first quarter of 2011. In July 2011, the ministry was still having trouble finalizing contracts for that year.

The pressure on prices from the defense industry together with the constant disagreements on prices led to that the Ministry of Defense established a special price department in 2011, in order to improve knowledge and transparency in relation to the price of military equipment. According to Serdiukov (2011), disagreement over prices is one of the prime causes of delays in defense industry contracts. In some cases, the defense industry has had a guaranteed level of profit of up to 25 percent, and given soft budget constraints in the form of large subsidies and favorable credits, the tendency has been to let all peripheral costs spill over in prices.

The large ineffective defense enterprises are still burdened by their own social service provisions (day-care centers, hospitals, etc.) and other high external costs (such as extremely long development times and unfinished projects). The Ministry has tried to force these enterprises to phase out their social commitments and let them be taken over by local municipalities, but the municipalities are reluctant to shoulder these tasks. In October 2011, Serdiukov discussed the Ministry of Defense's 491 pre-schools with Medvedev, who sternly requested a list of the municipalities that were refusing to take them over, clearly intending to put pressure on the local authorities concerned. For 2011, the Ministry is requiring the industry to reduce its average level of profit from 15 percent to five percent. Enterprises producing priority equipment, however, are to be allowed to raise their margins to 25 percent. Priority equipment refers to 200 products, including nuclear weapons, intercontinental ballistic missiles, cruise missiles, and other advanced arms that are in high demand. A further change is a plan by the Ministry to boost pre-payments from 15-40 percent to 80 percent. This means that the enterprises will have less financing problems during production, but also that subcontractors should be paid sooner.

Government arms procurement comes under the Official Secrets Act, and details of the annual value and composition of procurements belong to the classified section of the federal budget. The lack of transparency has led researchers to add together data from different sources and produce their own estimates. Thanks to a statement by Viktor Zavarzin, head of the State Duma Defense Committee, data were made available in 2016 relating both to the 2010 defense budget and to the budget for 2014-2016.

\section{The Geopolitical Race Between Russia and US Decides Their Influence on the World}

Both the historical and geographical aspects of the concept of geopolitics were developed in 1899, when the idea was originally proposed by the Swedish political scientist Rudolf Kjellen. It was the world view of Western imperialists who aimed to expand the European geographical sphere of influence to the rest of the world in order to seize more resources. It therefore indicates the hierarchical relationships in the European centralized ontology. The concept was extended by the Nazis to mean a fight for more territory. Given this 
expansionist context, the term "geopolitics" was out of favour until the US Secretary of State, Henry Kissinger, used it to define the global contest between the United States and the Soviet Union (O'Tuathail, 1998).

Geopolitics can be used as a theoretical research tool in the field of political rhetoric to make foreign policy decisions. From this diplomatic viewpoint, the word of geopolitics analytically frames the policy-making process in terms of national interests rather than ideology. During the Cold War period, Kissinger defined it as an approach that focused on the requirements of equilibrium, emphasizing the "balance of power". Secondly, the meaning of geopolitics assumes that geographical factors influence most national interests; this is taken for granted by policy-makers aiming to ensure global security and a military presence in various regions. Halford Mackinder has defined it as the exploitation of armed forces by economic wants and geographical opportunities to obtain political objectives (Gray \& Sloan, 1999).

The dominant geopolitical view arose from the European-American experience and was then projected onto the rest of the world and into the future theory and practice of world politics. To think about the geopolitical framing of foreign policies is to recall the doctrines enunciated by various US presidents, from Monroe in 1823 through Truman in 1947, and G. W. Bush in 2002. The Monroe Doctrine initially involved three geopolitical imperatives relating to the US foreign policy: The Americas were closed to further European colonization; the United States must avoid becoming involved in wars in Europe; and the US government would regard efforts made by any European power to expand its empire into the Western hemisphere as a threat to the United States itself. During the Johnson and Reagan presidencies, this doctrine was invoked to justify the US military intervention in many parts of the Latin America. John Agnew has envisioned world politics by regarding the modern geopolitical imagination in multiple ways, rather than as a simple reflection of competing geopolitical and national interests and the "identities" of fetishized states (Agnew, 2003).

Ratzel's study of the way in which human society is shaped by the natural environment has not only led to the sub-field of political geography but has also fed into the study of strategic studies, both in its Anglo-American and Nazi manifestations. The historical trend was from smaller peripheral to larger continental states. Technological developments from the age of discovery had benefited both sea and land powers. Maritime technology had allowed the states of Western Europe to circumnavigate the physical barriers that had penned them in and turned the ocean from an obstacle to a highway. At the same time those at the Eastern margins - Russia — had succeeded in conquering the pivot area of central Asia (Ashworth, 2011).

Eurasia is home to most of the world's politically assertive and dynamic states. All of the historical pretenders to global power originated in Eurasia. The world's most populous aspirants to regional hegemony, China and India, are in Eurasia, as are all the potential political or economic challengers to American primacy. Eurasia accounts for 75 percent of the world's population, 60 percent of its GNP, and 75 percent of its energy resources. Collectively, Eurasia's potential power overshadows even America's. Eurasia is the world's axial supercontinent. A power that dominated Eurasia would exercise decisive influence over two of the world's three most economically productive regions, Western Europe and East Asia. A glance at the map also suggests that a country dominant in Eurasia would almost automatically control the Middle East and Africa. With Eurasia now serving as the decisive geopolitical chessboard, it no longer suffices to fashion one policy for Europe and another for Asia. What happens with the distribution of power on the Eurasian landmass will be of decisive importance to America's global primacy and historical legacy. (Brzezinski, 1997, p. 51)

Eurasianism and geopolitics have become theoretical and doctrinal manifestations of the geomentality of Russia's foreign and security policy establishment. Political thinking about the importance of geographical space has strong intellectual and academic roots in Russia. The idea of Eurasianism emerged in 1920 and re-emerged in the 1990s. The decision on NATO enlargement helped Eurasianist ideas to emerge as the 
dominant doctrine in Russia's foreign and security policy. The NATO enlargement issue united Russia's political class in their opposition to this policy. The 1999 NATO-Yugoslavia war convinced the majority of Russians that Eurasians had always been right in their criticism of the West, NATO, and the Russian Liberals (Tchantouridze, 2001). Afterwards, the Russian authority has begun to adopt defensive realism to formulate its foreign and security policy. This direction has made the Russian president powerful, as several presidencies have resisted Western geopolitical expansion through NATO enlargement and economic sanctions against Russia. The distrust between the West and Russia have consolidated Eurasianism as a national identity and broadened its development in the East under the strategy of "Pivoting to Asia".

Realist and imperialist frames have dominated analyses of Russia's foreign policy under the leadership of Vladimir Putin. In one concept associated with defensive realism, Russia has been viewed as a status quo great power state seeking to preserve its position in the international system by maintaining the balance of power threatened by the US. From this standpoint, Russia's decision to annex Crimea stemmed from its desire to contain and balance the US. Prior Western activities, such as NATO's enlargement, prompted Russia's pushback when the opportunity presented itself. In another argument informed by offensive realism, Russia has been portrayed as a revisionist power harbouring aggressive intentions and pursuing the goal of power-aggrandizement. According to the theory of offensive realism, Russia's decision to invade Crimea was rational and expected, as it allowed the Kremlin to acquire the requisite strategic control over a vital military security asset (Omelicheva, 2016).

Robert Dannenberg, Frank J. Cilluffo, and Sharon L. Cardash (2014) had argued that the Crimea event should be understood through a geopolitical analysis of Putin's Russia. Russia moved to annex Crimea; the speed and audacity of the action shook Eastern Europe and surprised the West. The West used economic sanctions to counterattack, resisting the influence of geopolitical change after the collapse of the Union of Soviet Socialist Republics (USSR). Putin views sanctions as an opportunity to rebuild areas of the Russian economy that have suffered since the collapse of the Soviet Union and to reverse the increasing emphasis of the Russian economy on exporting commodities and importing manufactured goods. Putin wishes to use sanctions to change the world's macroeconomic paradigm. He has begun his own "Pivot toward Asia", finding an increasingly sympathetic audience in China. The Ukraine is the first step in Putin's campaign to reject the West culturally, economically, and strategically, in favour of a genuine and meaningful pivot toward the East. To make it all work, however, he needs China, Iran, and India-which is one reason why the Shanghai Cooperation Organization (SCO) is more important than people give it credit for. In any case, Putin calculates that one important element in Russia's ability to withstand Ukraine-related sanctions is his personal relationship with Chinese President Xi Jinping, along with a series of economic and energy agreements. Finally, Putin is putting a lot of energy into building up the Eurasian Union as a regional counterpart to the EU and an instrument for Moscow to use to exert influence over its neighbours.

In other words, Russia's geopolitical strategy plays a key role in strengthening its power in the regions. The Black Sea gives Russia navy ports for its Black Sea Fleet and the ability to construct pipelines to Europe; these enhance Russia's influence on Europe and the Middle East and strengthen Russia's national security. Russia relies on this energy supply to support its federal budget. Energy is considered to be the most important strategic resource leveraging geopolitical influence. After the Crimean event, the Western block regarded Russia's actions as a form of aggression. For this reason, they launched a series of economic sanctions to pressure Russia. Western economic sanctions have strengthened the liberal ideological and military block but 
hampered the construction of Russia-EU gas pipelines and collaboration in other areas, such as fighting international terrorism. President Putin decided to boost his Asian strategy through a "Pivot to Asia" and has therefore promoted Russian geopolitical influence in the Asian Pacific Region. This strategy is helping Russia develop the economy of the Far East Region to integrate it better into North Eastern Asia, through which its path extends to South Asia. Russia has promoted its role in the Korean Peninsula and intensified the geopolitical wrestling among China, Japan, and the United States. Russia and China have used this new situation to work more closely together to map peace-route plans in international conflict regions. This approach could provide a similar arena for pursuing Russia-US relations.

The added external pressure on the Russian oil and gas industry stems from the increased EU and US sanctions announced on 12 September 2014, which specifically target Russia's energy, defence, and financial industries. The oil and gas sector is affected by the limited access to financing and by limitations on technology transfer for unconventional and offshore developments. While the sanctions have specifically focused on exploration and production from offshore and unconventional resources in Russia, their effect has spread through the entire oil and gas industry. In response to sanctions, the Russian government and industry operators have intensified their focus on partnerships with Asia-based interests. When the South Stream gas pipeline to Europe was cancelled, an immediate alternative for Russian gas was proposed by President Putin - a sub-sea pipeline under the Black Sea to deliver gas to Turkey. In addition to replacing the South Stream project with this Turkey-bound gas pipeline, Russia and China have signed a memorandum of understanding on 9 November to build another gas pipeline. The new pipeline, "Altai", will connect Russia's West Siberian fields to the Xinjiang Uyghur Autonomous Region of China. The pipeline will run to the West of the Power of Siberia ("Sila Sibiri") pipeline announced in May 2014, which connects East Siberian fields to China's Eastern provinces (Global Data, 2014). The gas pipeline has guaranteed Russia-China relations and deepened the comprehensive strategic partnership of coordination.

\section{Conclusion for Further Discussion}

Assuming that the security policy situation remains unchanged, the most important factors determining the size of Russia's military expenditure are GDP growth and how well the Ministry of Defense and the defense lobby are able to negotiate in relation to other ministries and budget chapters in the federal budget process.

Many scholars and analysts believe that confrontation between the United States and Russia will continue in the adversarial atmosphere created by the Ukraine crisis and Russiagate. Neither Russian nor U.S. experts believe that Russia or the United States can afford to start a nuclear war, but both sides have to find ways to reduce the escalating tension by agreeing on concrete issues for negotiation and cooperation. The West regards the Ukraine crisis and Russiagate as examples of Russian aggressive geopolitical behaviour, ranging from economy-driven aggression to cybersecurity-based information warfare. The West therefore feels that Russia is challenging their national security; they need to counterattack against Russia's geopolitical ambitions through economic sanctions and military deterrence. This response is creating a new balance of power; it changed after the end of the Cold War and the start of NATO enlargement. The dilemma is that Russia has been too strong to compromise with the U.S. in its geopolitical games, for example in the Ukraine and Syria. What price will the Trump administration pay to achieve normalization with Russia? Putin is very serious about overcoming difficulties related to economic sanctions and low energy prices through a geostrategy involving Asia and the Eurasian regions. The Russia-China strategic comprehensive partnership seems to have deepened in the face of 
US-Russian adversarial relations. This will give China a broader chessboard to implement its own geopolitical strategy under the "One-Belt-One Road" economic plan. Russia and China have consolidated their Eurasian strategies to counterattack the Western Liberal International order to meet their national interests and demands. If the United States cannot normalize relations with Russia, North Korea, Iran, and other states will develop nuclear weapons to guard against external threats in an unstable and uncertain world. US-Russia relations therefore determine global security more than any other international relationship. U.S. and Russian experts on both sides have suggested resuming the dialogue to limit nuclear weapons; the balance of nuclear deterrence with the signing of periodic treaties to control the global security has created the present international order. There is less space for Russia to concede. The next move on the chessboard depends on Trump's ability to stop the Russiagate investigation and cooperate with Russia.

From a foreign policy perspective, the Kremlin has concluded the PMC model is a useful tool. It will continue to experiment with PMCs as part of its competition with the West—a struggle in which the Kremlin will use any tool it has in its arsenal, without any concern for human rights, neither of its own citizens nor those of other countries. This means wherever Russian PMCs appear, the West should pay attention, even when the Kremlin denies any knowledge of these groups or downplays their importance.

The revolution of the PMC model shows soft power of Putin's foreign policy in the Middle East and Africa, where Putin has worked to build leverage and connections with all major actors, rather than openly taking sides. PMCs are one tool of many in his arsenal.

The PMC model will evolve and expand insofar as the Kremlin sees it as successful in achieving foreign policy objectives. For Moscow, this means its focus on weakening the West in a zero-sum effort to prop up its own position. Analysts must study PMC groups in greater depth, examining their structure and operations, looking beyond their plausible deniability as the only explanation for their use. In the end, as PMCs play a larger role in the Kremlin's foreign policy, the West needs better solutions for countering Russian them.

\section{References}

Abrams, E. (2017). The trump national security strategy. Council on Foreign Relations. Retrieved from https://www.cfr.org/blog/trump-national-security-strategy

Agnew, J. (2003). Geopolitics: Re-visioning world politics. London \& New York: Routledge. Retrieved from https://books.google.com.tw/books?id=G8PKbsgXLNoC\&printsec=frontcover\&dq=geopolitics\&hl=zh-TW\&sa=X\&ved=0a hUKEwijppW_7tnYAhXIWbwKHaXVD5sQ6AEINDAC\#v=onepage\&q=geopolitics\&f=false

Allison, G. (2015). The Thucydides trap: Are the US and China headed for war? The Atlantic. Retrieved from https://www.theatlantic.com/international/archive/2015/09/united-states-china-war-thucydides-trap/406756/

Allison, G. (2017). America and Russia: Back to basics. National Interest. Retrieved from http://nationalinterest.org/feature/america-russia-back-basics-21901

Ashworth, L. M. (2011). Realism and the spirit of 1919: Halford Mackinder, geopolitics and the reality of the League of Nations. European Journal of International Relations, 17(2), 208-286.

Brzezinski, Z. (1997). A geostrategy for Eurasia. Foreign Affairs, 76(5), 50-64.

Cesa, M. (2009). Realist visions of the end of the Cold War: Morgenthau, Aron and Waltz. The British Journal of Politics and International Relations, 11(2), 177-191.

Dannenberg, R., Cilluffo, F. J., \& Cardash, S. L. (2014). Putin's Russia: A geopolitical analysis. HSPI Issue Brief 24, Homeland Security Policy Institute. Retrieved from https://cchs.gwu.edu/sites/cchs.gwu.edu/files/downloads/Issue\%20BriefPutin\%27s\%20Russia-\%20A\%20Geopolitical\%20A nalysis.pdf

Escobar, P. (2017). There will be no Russia phobia reset. Sputnik. Retrieved from https://sputniknews.com/columnists/201704271053078743-there-will-be-no-russophobia-reset/ 
Gearan, A., \& Mufson, S. (2017). Trump sets out national security strategy of "principled realism" and global competition. Washington Post. Retrieved from https://www.washingtonpost.com/politics/trump-sets-out-national-security-strategy-of-principled-realism-and-global-compet ition/2017/12/18/7edcb0be-e412-11e7-ab50-621fe0588340_story.html?utm_term=.2387b435ce47

Global Data. (2014). Russian oil and gas landscape reshaped by geopolitics. London: Global Data.

Gray, C. S., \& Sloan, G. (1999). Geopolitics, geography and strategy. London \& New York: Routledge. Retrieved from https://books.google.com.tw/books?id=7BakAgAAQBAJ\&printsec=frontcover\&dq=geopolitics\&hl=zh-TW\&sa=X\&ved=0a hUKEwijppW_7tnYAhXIWbwKHaXVD5sQ6AEIJTAA\#v=onepage\&q=geopolitics\&f=false

International Committee of the Red Cross (ICRC). (2009). The Montreux document: On pertinent international legal obligations and good practices for states related to operations of private military and security companies during armed conflict. Geneva: ICRC. Retrieved from https://www.icrc.org/en/doc/assets/files/other/icrc_002_0996.pdf

Ivanov, I. (2018). Russia and Europe: From romanticism to pragmatism. RIAC. Retrieved from http://russiancouncil.ru/en/analytics-and-comments/analytics/russia-and-europe-from-romanticism-to-pragmatism/

Karaganov, S. (2017). A Cold War: A forecast for tomorrow. Russia in Global Affairs. Retrieved from http://eng.globalaffairs.ru/pubcol/A-Cold-War-A-Forecast-for-Tomorrow-19099

Khalilzad, Z. (2017). The path to US-Russia cooperation. National Interest. Retrieved from http://nationalinterest.org/feature/the-path-us-russia-cooperation-21914

Khudoley, K. (2017). Russia and the U.S.: The way forward. Russia in Global Affairs. Retrieved from http://eng.globalaffairs.ru/number/Russia-and-the-US-The-Way-Forward-19263

Kortunov, A. (2017a). Policy priorities in US-Russia relations. RIAC. Retrieved from http://russiancouncil.ru/en/activity/policybriefs/policy-priorities-in-us-russia-relations/

Kortunov, A. (2017b). A roadmap for US-Russia relations. RIAC. Retrieved from http://russiancouncil.ru/en/activity/publications/a-roadmap-for-u-s-russia-relations/

Kortunov, A. (2018a). How should Russia respond to an adversarial west? RIAC. Retrieved fromhttp://russiancouncil.ru/en/analytics-and-comments/analytics/how-should-russia-respond-to-an-adversarial-west/

Kortunov, A. (2018b). Dialogue with US on nuclear-missile weapons is Russia's priority task. RIAC. Retrieved from http://russiancouncil.ru/en/analytics-and-comments/comments/dialogue-with-us-on-nuclear-missile-weapons-is-russia-s-prior ity-task/

Lenta.ru. (2018). Головорезы с тесакаминаперевес. Retrieved from https://lenta.ru/arti-cles/2018/02/21/chvkinterview/

Likhachev, V. (2017). Russia-EU energy relations. RIAC. Retrieved from http://russiancouncil.ru/en/activity/publications/russia-eu-energy-relations/

Locker, R. (2016). What's the arms race? A short history. USA Today. Retrieved from https://www.usatoday.com/story/news/politics/2016/12/23/whats-arms-race-short-history/95792412/

Macklem, P. (2008). Humanitarian intervention and the distribution of sovereignty in international law. Ethics \& International Affairs, 22(4), 369-393.

Mate, A. (2017). Russiagate is more fiction than fact. The Nation. Retrieved from https://www.thenation.com/article/russiagate-is-more-fiction-than-fact/

Morgenthau, H. J. (1973). Politics among nations: The struggle for power and peace (7th ed.). Boston: McGraw-Hill Higher Education

Myers, R. J. (1997). Hans Morgenthau's realism and American foreign policy authors. Ethics \& International Affairs, 11(1), 253-270.

Norwegian Defence Research Establishment (FFI). (2018). Russian use of private military and security companies-The implications for European and Norwegian Security. Retrieved from https://www.cmi.no/publications/file/6637-russian-use-of-private-military-and-security.pdf

Nye, J. S. Jr. (2015). Is the American century over? Wiley. Retrieved from https://www.wiley.com/en-us/Is+the+American+Century+Over\%3F-p-9780745690063\#

Nye, J. S. Jr. (2017). Will the liberal order survive? The history of an idea. Foreign Affairs. Retrieved from https://www.foreignaffairs.com/articles/2016-12-12/will-liberal-order-survive

O’Tuathail, G. (1998). Thinking critically about geopolitics. In G. O’Tuathail, S. Dalby, and P. Routledge (Eds.), The geopolitics reader.

Retrieved fromhttps://books.google.com.tw/books?id=VH2FAgAAQBAJ\&printsec=frontcover\&dq=geopolitics\&hl=zh-TW\&sa=X\&v ed=0ahUKEwijppW_7tnYAhXIWbwKHaXVD5sQ6AEILTAB\#v=onepage\&q=geopolitics\&f=false 
Omelicheva, M. Y. (2016). Critical geopolitics on Russian foreign policy: Uncovering the imagery of Moscow's international relations. International Politics, 53(6), 708-726.

Podvig, P. (2011). Russia's nuclear forces: Between disarmament and modernization. Paris, Institute Français des Relations Internationals.

Reiter, D. (2014). Security commitments and nuclear proliferation. Foreign Analysis, 10(1), 61-80.

Roberts, P. C. (2018). Russiagate turns on its originators. Foreign Policy Journal. Retrieved from https://www.foreignpolicyjournal.com/2018/01/09/russiagate-turns-on-its-originators

Rose, G. (2017). Introduction, from the anthology: What was the liberal world? Foreign Affairs. Retrieved from https://www.foreignaffairs.com/articles/2017-03-06/introduction

Sears, N. A. (2017). What might Morgenthau have to say about the administration's emerging foreign policy? National Interest. Retrieved from http://nationalinterest.org/feature/trump-can-learn-morgenthaus-6-principles-political-realism-19481

Simes, D. (2017). Current mutual hostility threatens an explosive confrontation. National Interest. Retrieved from http://nationalinterest.org/feature/the-costs-ignoring-russia-21888

Strong, A. (2017). Trump promotes Reagan Era "peace through strength" in national security strategy. CBN. Retrieved from https://www1.cbn.com/cbnnews/national-security/2017/december/trump-promotes-reagan-era-peace-through-strength-in-nati onal-security-strategy

Sukhankin, S. (2019). Unleashing the PMCs and Irregulars in Ukraine: Crimea and Donbas. September 3, 2019. Retrieved from https://jamestown.org/program/unleashing-the-pmcs-and-irregulars-in-ukraine-crimea-and-donbas/

Tchantouridze, L. (2001). Awakening of spirits: Eurasianism and geopolitics in the foreign policy of Russia. Canada: ProQuest Dissertations Publishing.

The Federal Council of Switzerland, Federal Department of Foreign Affairs. (2008). Participating States of the Montreux Document. Retrieved

from https://www.eda.admin.ch/eda/en/home/foreign-policy/international-law/international-humanitarian-law/private-military-sec urity-companies/participating-states.html

The Swedish Defence Research Agency (FOI). (2009). Russian Military Capability in a ten-year perspective: Ambitions and challenges in 2008. Retrieved from https://www.foi.se/rest-api/report/FOI-R--3474--SE

TNI Staff. (2017). A symposium on US-Russia relations in the age of Trump. National Interest. Retrieved from http://nationalinterest.org/feature/america-russia-permanent-confrontation-21891

United Nations Human Rights, Office of the High Commissioner. (2001). International Convention against the Recruitment, Use, Financing and Training of Mercenaries: Adopted and opened for signature and ratification by General Assembly resolution 44/34 of 4 December 1989. Retrieved from https://www.ohchr.org/EN/ProfessionalInterest/Pages/Mercenaries.aspx

$\mathrm{Wu}$, D. D. (2017). Russia-China relations reach a new high. The Diplomat. Retrieved from https://thediplomat.com/2017/07/russia-china-relations-reach-a-new-high/ 